\title{
Electron Microscopic Studies on Reticular Fibers in the Pig Sheathed Artery and Splenic Cords
}

\author{
Hiroto MIYATA, Mitsuo ABE, Kazushige TAKEHANA, Kenji IWASA, and Takeo HIRAGA \\ Department of Veterinary Anatomy, School of Veterinary Medicine, Rakuno Gakuen University, Ebetsu, Hokkaido 069, Japan
}

(Received 15 February 1993/Accepted 22 June 1993)

ABSTRACT. The reticular fibers of the capillary sheath and splenic cord were studied in the pig spleen by transmission electron
microscopy to reveal their components and the presence of sialic acid in the amorphous ground substance. Collagen fibrils, elastic fibers,
microfibrils, nerve fibers and smooth muscle cells were observed in the reticular fibers of the splenic cord, while only microfibrils were
recognized in the reticular fibers of the capillary sheath. The binding of LFA lectin to the splenic cord was stronger than the capillary
sheath. These findings may suggest that the reticular fibers of the splenic cord include numerous functional elements and perform an
important role during contraction or dilation of the spleen. On the other hand, it seems to be reasonable to term the capillary sheath as
"capillary basement membranous reticular tissue", since the reticular fiber of the capillary sheath resembles the basement membrane of
the capillary in its components.-KEY wORDs: LFA lectin, reticular fiber, sheathed artery, splenic cord, swine.

The sheathed artery is a characteristic structure in the spleen, consisting of a capillary lined with high endothelial cells and a capillary sheath surrounding the capillary concentrically. The capillary sheath has been called Kapillarhüllse [23, 31, 37], Arterielles Gefäß (Hülse) [22], ellipsoid [3, 5, 14, 24, 39], Schweigger-Seidel sheath [39] or periarterial macrophage sheath (PAMS) $[3-5,40]$. It is a reticular tissue composed of reticular cells and fibers, and forms denser network than that in the splenic cords. It varies in shape and size according to the species, and develops best in the pig among domestic animals [8, 38].

Recently, electron microscopic and biochemical investigations have demonstrated that the intercellular substance contains various fibrous proteins wrapped by proteoglycan and glycoprotein. In the extracellular matrix, terminal sugar residues of glycoproteins are rich in sialic acid [2]. On the other hand, the reticular fibers in the intercellular substance of the spleen are known to be argyrophilic [9, 12, 15, 16, 22, 24, 29, 30, 35, 39]. Electron microscopic studies on the spleen of the rat [35] and the guinea pig [34] lacking the sheathed artery revealed reticular fibers containing several fibrous proteins to form reticular meshwork, but remained details of the other components unknown. In the present study on the pig spleen, therefore, we compared components of the reticular fiber and contents of sialic acid in the capillary sheath with those in the splenic cords by transmission electron microscopy.

MATERIALS AND METHODS

Five 6-month-old crossbred pigs (Landrace, Large White and Hampshire) weighing about $100 \mathrm{~kg}$ were used as materials.

For electron microscopy, the spleen was removed just after the slaughter and perfused through the splenic artery with Ringer's solusion containing heparin $(10,000 \mathrm{IU} / l)$ followed by $3 \%$ glutaraldehyde in $0.1 \mathrm{M}$ phosphate buffer $(\mathrm{pH} 7.2)$ at room temperature. Then, the spleen was cut into small pieces $(1 \times 1 \times 1 \mathrm{~mm})$ and immersed in the same fixative for additional $2 \mathrm{hr}$ at room temperature. After fixation, tissue blocks were rinsed in the same buffer, dehydrated through a graded series of ethanol, and routinely embedded in Quetol 812 [26]. Ultrathin sections were prepared on a JUM-7 ultramicrotome with a diamond knife and treated with tannic acid staining technique to increase the contrast of fibrous components of the connective tissue [19]. Electron micrographs were taken with a JEM-100S electron microscope under an accelerating voltage of $80 \mathrm{kV}$.

For the sialic acid detection, the spleen was removed and perfused as described above with Ringer's solution containing heparin $(10,000 \mathrm{IU} / l)$ followed by $4 \%$ paraformaldehyde- $0.5 \%$ glutarardehyde in $0.1 \mathrm{M}$ phosphate buffer (pH 7.2) at room temperature. Then, the spleen was cut into small pieces $(1 \times 1 \times 1 \mathrm{~mm})$, rinsed in the same buffer, dehydrated in a graded series of $\mathrm{N}, \mathrm{N}$-dimethylformamid at progressively lower temperatures and finally embedded in glycol methacrylate (GMA) [13] at $-20^{\circ} \mathrm{C}$. Ultrathin sections were incubated with gold-labeled Limax flarus agglutinin (LFA) lectin [28, 32] for a detection of sialic acid, and double-stained with uranyl acetate and lead citrate.

RESULTS

1) General histology

The splenic cords: The reticular tissue in the splenic cords was composed of reticular cells extending numerous processes, reticular fibers forming fine networks and smooth muscle cells filling their spaces. Many free cells were also present in the meshwork of the reticular tissue. The reticular fibers of the splenic cords were $780 \mathrm{~nm}$ in diameter on the average, and enfolded by the reticular 
cells or their cytoplasmic processes. The reticular fibers consist of 3 fibrous proteins as follows: collagen fibrils $40-50 \mathrm{~nm}$ in diameter to form bundles, microfibrils $13 \mathrm{~nm}$ in diameter to form irregular nets, and elastic fibers 160 $\mathrm{nm}$ in diameter with high electron density by tannic acid staining (Figs. 1, 2). The direction of collagen fibrils almost corresponded with the direction of cytoplasmic processes of the reticular cell. On the other hand, elastic fibers took irregular directions (Fig. 2). Microfibrils were mostly situated around elastic fibers. In addition, the reticular fibers enclosed several nerve fibers ensheathed by the Schwann cell and nerve terminals. Smooth muscle cells were also located in the bundle of reticular fibers (Fig. 3). Nerve fibers were frequently recognized in the bundle of reticular fibers with smooth muscle cells, but occasionally ensheathed by the Schwann cell and present in the bundle of reticular fibers without smooth muscle cells (Fig. 4). Nerve terminals were observed in the more slender bundle of reticular fibers.

The sheathed artery: The capillary sheath consisted of reticular cells and fibers forming denser networks than those of the reticular tissue of the splenic cord. The reticular fibers of the capillary sheath were $290 \mathrm{~nm}$ in diameter on the average, and more slender than the reticular fibers of the splenic cords. The reticular fibers in the capillary sheath were composed only of aggregation of microfibrils, and devoid of collagen fibrils, elastic fibers, nerve fibers and smooth muscle cells (Fig. 5). The reticular fibers and the basement membrane of the capillary were connected with each other (Fig. 6).

2) LFA lectin reactions

The reticular fibers of the splenic cords and the capillary sheath showed positive reactions to the LFA lectin. The reticular fibers of the splenic cords showed stronger reaction than the capillary sheath. The average number of gold particles per a unit area $(300 \times 300 \mathrm{~nm})$ was about fivefold as many in the former as in the latter (Figs. 7,8). The strength of the reaction to the LFA lectin closely resembled with each other between the reticular fibers of the capillary sheath and the basement membrane of the capillary (Fig. 9),

The present findings were summarized as in Table 1.

DISCUSSION

The reticular tissue of red and white pulps of the spleen consists of reticular cells and fine networks of the reticular fibers $[1,3-6,10,12,21,22,24,30,35,40]$. Recently, according to morphologic observations by electron microscopy, Saito et al. called the reticular fibers within the reticula of the reticular cells and their cytoplasmic processes "minimized connective tissue" in the spleens of rat and guinea pig. The minimized connective tissue included collagen fibrils, elastic fibers, microfibrils and nerve fibers [33-35]. Reticular fibers of the lymph node also had the same components [12]. On the other hand, the present study in the pig spleen revealed that the reticular fibers of the splenic cords contained smooth
Table 1. Components of the reticular fiber in the splenic cords and the capillary sheath and its reactivity to the LFA lectin

\begin{tabular}{lcc}
\hline & Splenic cord & Capillary sheath \\
\hline Collagen fibril & + & $-{ }^{\text {a) }}$ \\
Elastic fiber & + & - \\
Microfibril & + & + \\
Nerve fiber & + & - \\
Smooth muscle cell & + & - \\
LFA lectin & strong & weak \\
\hline
\end{tabular}

a) + : Presence, - : Absence.

muscle cells in addition to the components above described.

The type IV collagen organizes the basement membrane, but does not form a fibril $[2,41]$. In the present study, collagen fibrils were not contained in the basement membrane of the capillary. The reticular fiber of the capillary sheath may be similar in nature to that of the basement membrane of the capillary. In fact, the basement membrane of the capillary continuously transforms itself into reticular fibers in the capillary sheath composed of reticular tissues. There are two opinions at present as for the origin of the capillary sheath; one postulates its origin from the specialized vessel walls or adventitia [23, $31,37,42]$, while the other from reticular cells of the splenic pulp $[14,39]$. The present result seem to support the former one.

According to binding patterns of the LFA lectin showing specific reactivity for sialic acid, the reticular fibers of the splenic cord showed stronger binding to the lectin than the reticular fiber in the capillary sheath. In the extracellular matrix, terminals of sugar chains of glycoproteins are rich in sialic acid [2]. Therefore, the present results suggest that there are many glycoproteins in the splenic cord than in the capillary sheath. The binding pattern of LFA lectin to the reticular fibers in the capillary sheath is similar to those in the basement membrane. Glycoproteins in the amorphous ground substance of the capillary sheath seem to be similar to those in the basement membrane of the capillary.

The fibrous proteins may play various roles in the splenic cords as follows: elastic fibers give elasticity to the splenic cord during its contraction or dilation; collagen fibrils help expansion of the splenic cord. It seems that morphological changes of the fibrous proteins are controlled by smooth muscle cells through nerve fibers. As the capillary sheath does not contain elastic fibers, collagen fibrils, nerve fibers or smooth muscle cells, it is considered that the capillary sheath may play passive roles during contraction or dilation of the spleen.

Recently, an immunohistochemical study on the reticular fiber in the human spleen showed that reticular fibers in the splenic cord contain the basement membrane proteins, such as laminin and type IV collagen [25]. Although the present study did not try to demonstrate these basement membrane proteins in the reticular fibers, 


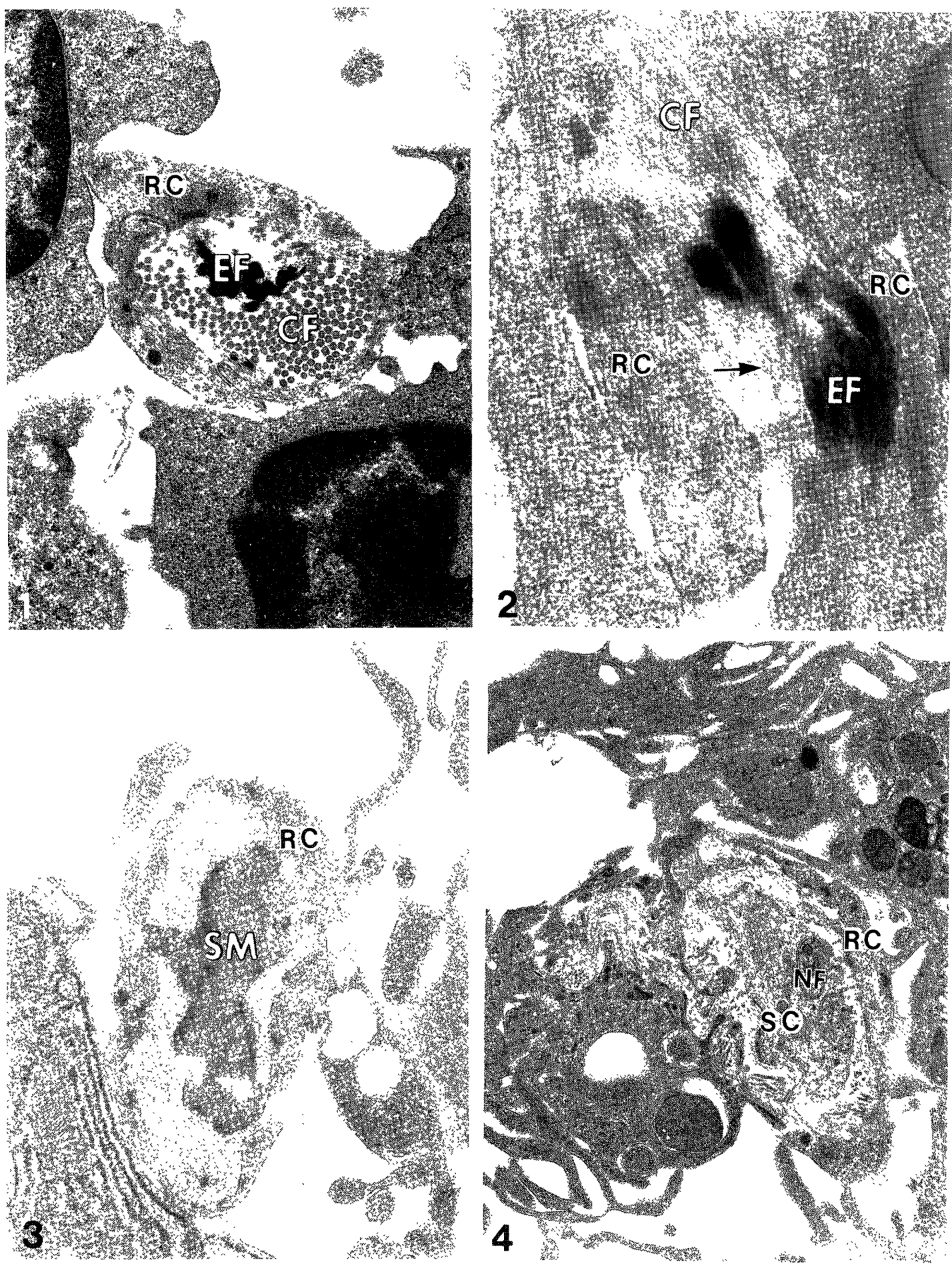

Fig. 1. Cross section of a reticular fiber in the splenic cord. Numerous collagen fibrils (CF) and elastic fibers (EF) are enfolded by cytoplasmic processes of reticular cells $(\mathrm{RC})$. Tannic acid staining. $\times 17,500$.

Fig. 2. Longitudinal section of a reticular fiber in the splenic cord. Collagen fibrils (CF) run almost parallel to cytoplasmic processes of the reticular cell (RC), while elastic fibers (EF) run in various directions. An arrow indicates microfibrils. Tannic acid staining. $\times 35,000$.

Fig. 3. Cross section of a reticular fiber in the splenic cord. Smooth muscle cells (SM) are enfolded by reticular cells (RC). Tannic acid staining. $\times 17,500$.

Fig. 4. A reticular fiber in the splenic cord. A nerve fiber (NF) with a Schwann cell (SC) and many collagen fibrils are present in the reticular fiber enfolded by cytoplasmic processes of the reticular cells (RC). Tannic acid staining. $\times 10,500$. 




Fig. 5. Cross section of a reticular fiber in a sheathed artery. The reticular fiber of the capillary sheath is more slender than that of the splenic cord, and is enfolded by cell bodies or cytoplasmic processes of the reticular cell (RC). Dense aggregation of microfibrils is seen in the reticular fiber. Tannic acid staining. $\times 70,000$.

Fig. 6. The basement membrane (BM) of a capillary. A reticular fiber and the basement membrane of an endothelial cell (EC) continue with each other (arrow head). Tannic acid staining. $\times 17,500$.

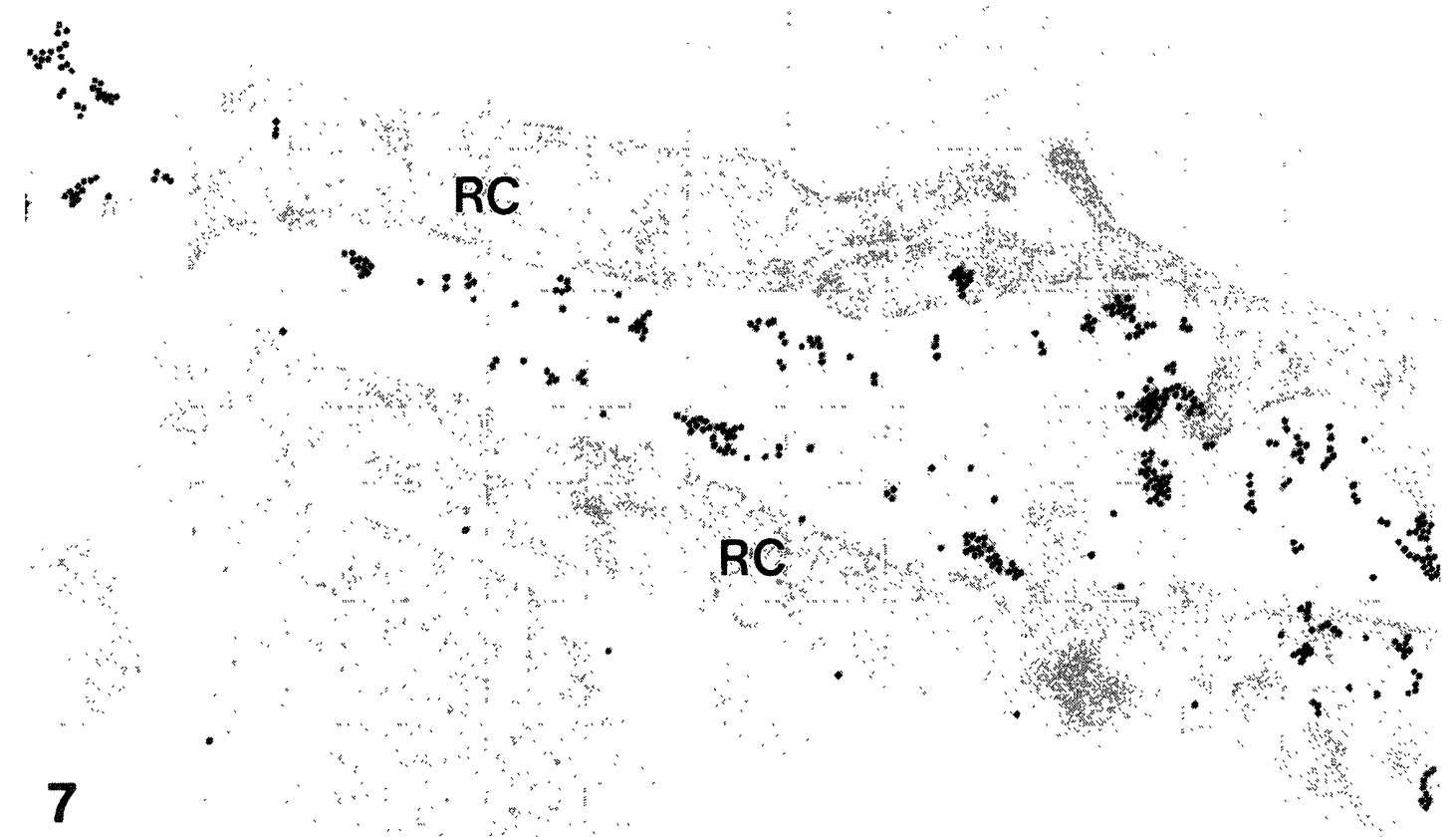

Fig. 7. Binding of the LFA lectin to a reticular fiber in the splenic cord. Numerous gold particles are present in the reticular fiber between the reticular cells $(\mathrm{RC})$. LFA lectin staining. $\times 45,000$. 


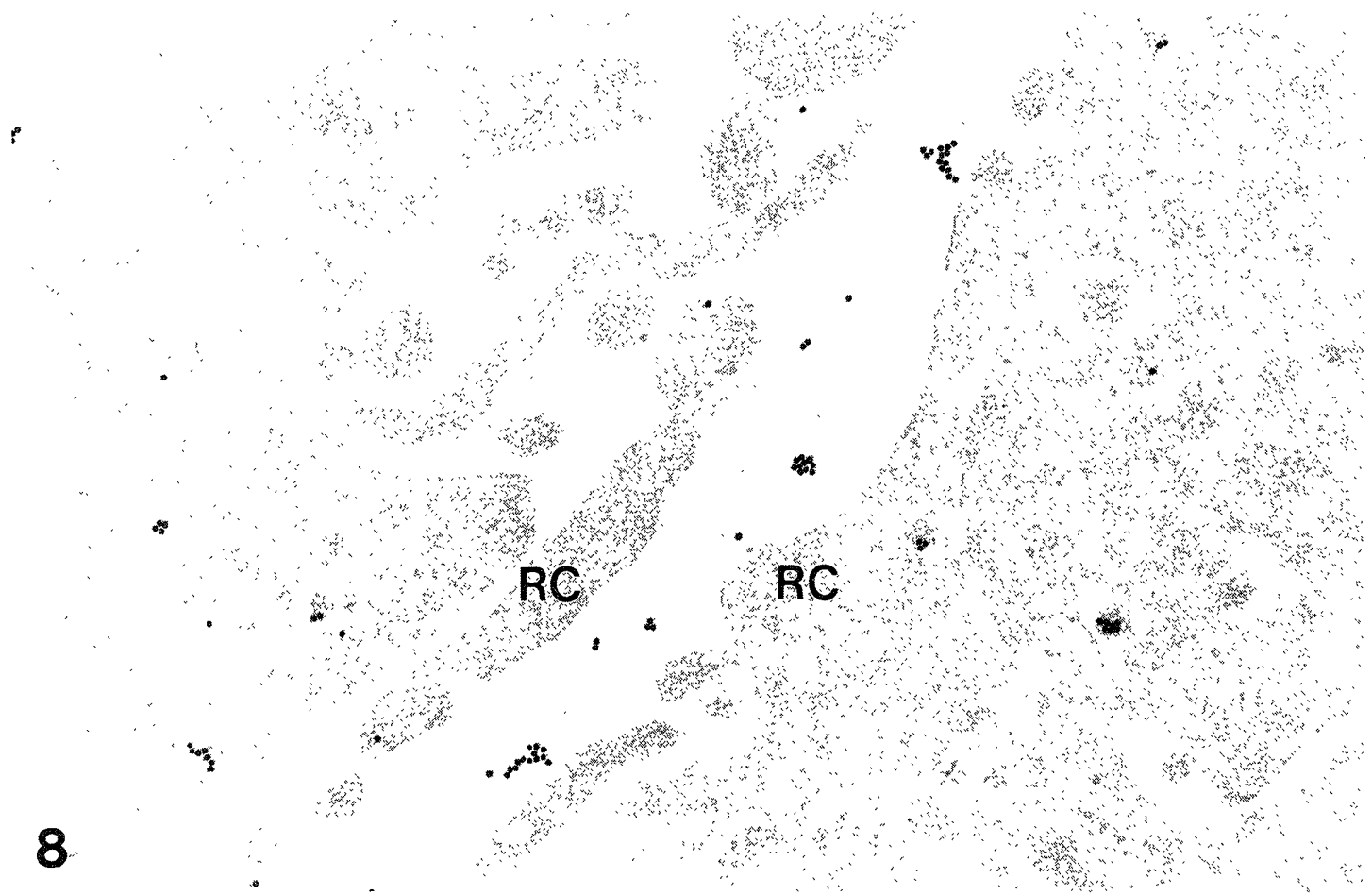

Fig. 8. Binding of the LFA lectin to a reticular fiber in a sheathed artery. Gold particles are observed less in number in the reticular fibers between the reticular cells $(\mathrm{RC})$ than in the splenic cord shown in Fig. 7. LFA lectin staining. $\times 45,000$.

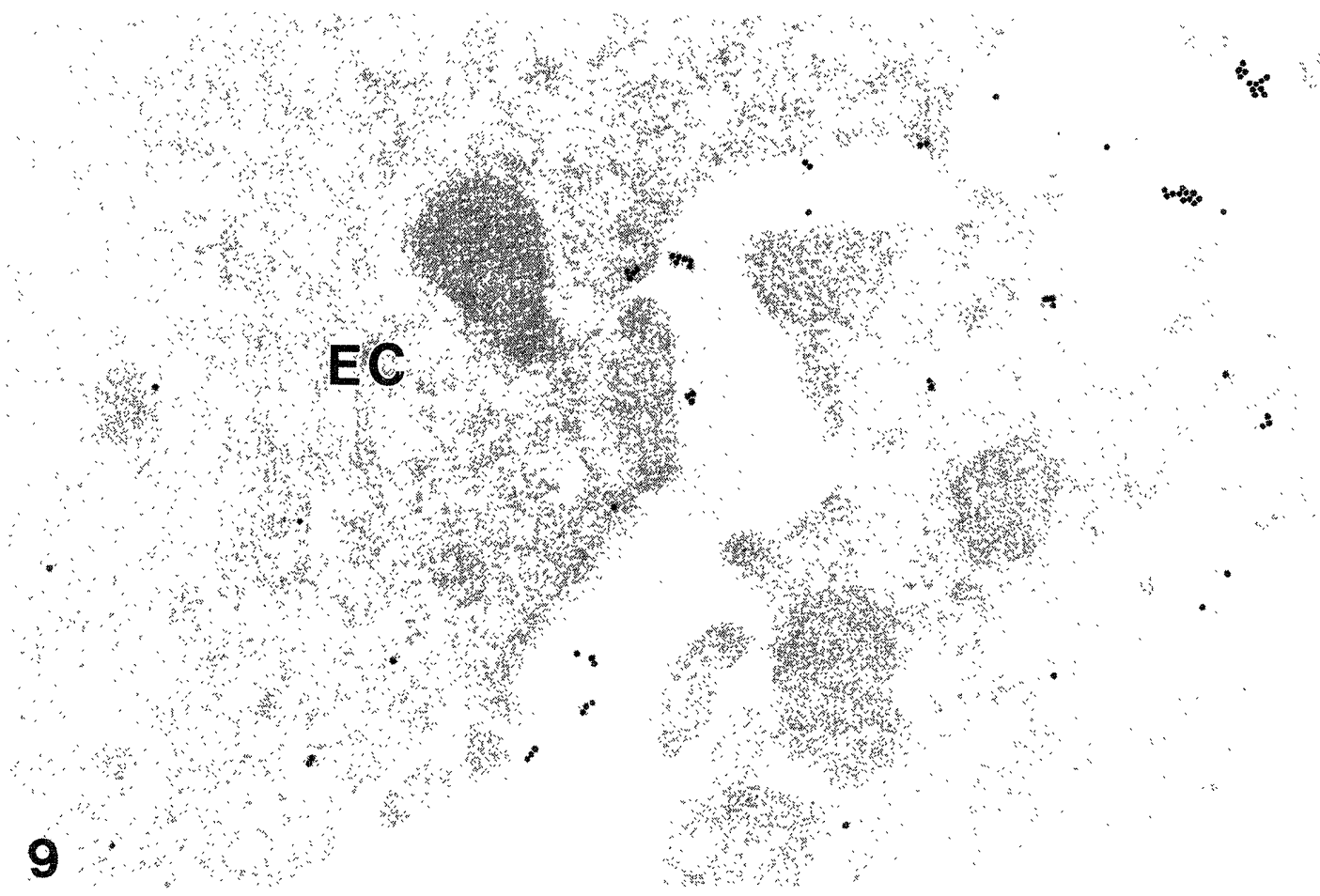

Fig. 9. Binding of the LFA lectin to the basement membrane of a capillary. The binding pattern of the lectin to the basement membrane of a endothelial cell (EC) closely resembles that to reticular fibers of the capillary sheath. LFA lectin staining. $\times 45,000$. 
the reticular fibers of the capillary sheath were clearly different from those of the splenic cord. It seems to be reasonable to term the capillary sheath as "capillary basement membranous reticular tissue", since the organization of fibrous proteins and the reactivity to carbohydrates resemble in the reticular fibers to those of the basement membrane of the capillary.

\section{REFERENCES}

1. Abe, M., Takehana, K., Iwasa, K., and Hiraga, T. 1989. Scanning electron microscopic studies on the red pulp of the mink spleen. Jpn. J. Vet. Sci. 51: 775-781.

2. Alberts, B., Bray, D., Lewis, J., Raff, M., Roberts, K., and Watson, D. W. 1989. Molecular Biology of the Cell, 2nd ed., Garland Publishing, New York.

3. Blue, J. and Weiss, L. 1981. Periarterial macrophage sheaths (ellipsoids) in cat spleen-An electron microscope study. Am. J. Anat. 161: 115-134.

4. Blue, J. and Weiss, L. 1981. Vascular pathways in nonsinusal red pulp-An electron microscope study of the cat spleen. Am. J. Anat. 161: 135-168.

5. Blue, J. and Weiss, L. 1981. Electron microscopy of the red pulp of the dog spleen including vascular arrangements, periarterial macrophage sheaths (ellipsoids), and the contractile, innervated reticular meshwork. Am. J. Anat. 161: 189-218.

6. Chen, L. and Weiss, L. 1972. Electron microscopy of the red pulp of human spleen. Am. J. Anat. 134: 425-458.

7. Clement, B., Rissel, M., Peyrol, S., Mazurier Y., Grimaud, J. A., and Guillouzo, A. 1985. A procedure for light and electron microscopic intracellular immunolocalization of collagen and fibronectin in rat liver. J. Histochem. Cytochem. 33: 407-414.

8. Dellmann, H. D. and Brown, E. M. 1981. Textbook of Veterinary Histology, 2nd ed., Lea \& Febiger, Philadelphia.

9. Drenckhahn, D. and Wagner, J. 1986. Stress fiber in the splenic sinus endothelium in situ: molecular structure, relationship to the extracellular matrix, and contractility. J. Cell Biol. 102: 1738-1747.

10. Fujita, T. 1974. A scanning electron microscope study of the human spleen. Arch. Histol. Jpn. 37: 187-216.

11. Harwood, R. 1979. Collagen polymorphism and messenger RNA. Int. Rev. Connect. Tissue Res. 8: 159-226.

12. Hayakawa, M., Kobayashi, M., and Hoshino, T. 1990. Microfibrils: a constitutive component of reticular fibers. Cell Tissue Res. 262: 199-201.

13. Hoshino, M. and Kobayashi, H. 1971. The use of glycol methacrylate as an embedding medium for the histochemical demonstration of acid phosphatase activity. J. Histochem. Cytochem. 19: 575-576.

14. Huech-Leipzig, H. W. 1928. Referat über die chronischen Milzvergrößerungen. Verh. Dtsch. Pathol. Ges. 23: 6-40.

15. Ishii, T. 1964. Das Silberbild der Retikulumfasern des Lymphknotens (mit besonderer Berücksichtigung des Übergangs in die kollagenen Fasern). Anat. Anz. 121: 353-359.

16. Ishii, T. 1968. Über den lichtmikroskopischen Feinbau der Retikulumfasern im Lymphknoten (ein Beitrag zur Frage der Natur der Retikulumfasern). Anat. Anz. 121: 487-494.

17. Junqeira, L. C. U. and Montes, G. S. 1983. Biology of collagen-proteoglycan interaction. Arch. Histol. Jpn. 46: 589-629.
18. Kajikawa, K. 1957. Electron microscope studies on the intercellular substance of connective tissue. J. Juzen Med. Soc. 59: 277-297 (in Japanese).

19. Kajikawa, K., Yamaguchi, T., Katsuda, S., and Miwa, A. 1975. An improved electron stain for elastic fibers using tannic acid. J. Electronmicrosc. 24: 287-289.

20. Karttunen, T., Sormunen, R., Risteli, L., Risteli, J., and Autio-Harmainen, H. 1989. Immunoelectron microscopic localization of laminin, type IV collagen, and type III pN-collagen in reticular fibers of human lymph nodes. $J$. Histochem. Cytochem. 37: 279-286.

21. Kashimura, M. and Fujita, T. 1987. A scanning electron microscopy study of human spleen: relationship between the microcirculation and functions. Scan. Microsc. 1: 841-851.

22. Koboth, I. 1939. Über das Gitterfasergerüst der roten Milzpulpa mit einem Beitrag zu ihrer Gefäßstruktur und Blutdurchströmung. Beitr. Pathol. Anat. Allg. Pathol. 103: 11-29.

23. Kyber, E. 1879. Ueber die Milz des Menschen und einiger Säugetiere. Arch. Mikrobiol. Anat. 6: 540-582.

24. Li, P. L., Mole, R. H., and Garven, H. 1929. The minute anatomy of the vascular system of the dog's spleen. China Med. J. 43: 757-767.

25. Liakka, A., Apaja-Sarkkinen, M., Karttunen, T., and Autio-Harmainen, H. 1991. Distribution of laminin and types IV and III collagen in fetal, infant and adult human spleens. Cell Tissue Res. 263: 245-252.

26. Luft, J. H. 1973. Advanced Techniques in Biological Electron Microscopy. Springer-Verlag, Berlin, Heidelberg and New York.

27. Minor, R. R. 1980. Collagen metabolism. Am. J. Pathol. 98: $227-280$.

28. Muller, C. and Baigent, C. L. 1980. Antigen controlled immunodiagnosis-acid test. J. Immunol. Methods 37: 185-190.

29. Montes, G. S., Krisztan, R. M., Sigihara, K. M., Tokoro, R., Mourao, P. A. S., and Junqeira, L. C. U. 1980. Histochemical and morphological characterization of reticular fibers. Histochemistry 65: 131-141.

30. Pabst, R. and Binns, R. M. 1982. The three-dimensional reticular structure of the pig spleen demonstrated by labelling with fluorescein isothiocyanate. Cell Tissue Res. 226: 319-325.

31. Riedel, H. 1932. Das Defässsystem der Katzenmilz. Z. Zellforsch. 15: 459-529.

32. Roth, J. 1983. The colloidal gold marker system for light and electron microscopic cytochemistry. pp. 217-284. In: Techniques in Immunocytochemistry (Bullock, G. and Petrusz, P. eds.), Academic Press, London.

33. Saito, H. 1977. Fine structure of the reticular cells in the rat spleen, with special reference to their fibro-muscular features. Arch. Histol. Jpn. 40: 333-345.

34. Saito, H. 1990. Innervation of the guinea pig spleen studied by electron microscopy. Am. J. Anat. 189: 213-235.

35. Saito, H., Yokoi, Y., Watanabe, S., Tajima, J., Kuroda, H., and Namihisa, T. 1988. Reticular meshwork of the spleen in rats studied by electron microscopy. Am. J. Anat. 181: 235-252.

36. Sano, J., Sato, S., Ishizaki, M., Yajima, G., Konomi, H., Fujiwara, S., and Nagai, Y. 1981. Types I, III and IV (basement membrane) collagens in the bovine liver parenchyma: electron microscopic localization by the peroxidaselabeled antibody method. Biomed. Res. 2: 546-551. 
37. Schweigger-Seidel, F. 1863. Untersuchungen über die Milz. Virchow's. Arch. 27: 460-506.

38. Seki, A. and Abe, M. 1985. Scanning electron microscopic studies on the microvascular system of the spleen in the rat, cat, dog, pig, horse, and cow. Jpn. J. Vet. Sci. 47: 237-249.

39. Solnitzky, O. 1937. The Schweigger-Seidel sheath (ellipsoid) of the spleen. Anat. Rec. 69: 55-75.
40. Tablin, F. and Weiss, L. 1983. The equine spleen: an electron microscopic analysis. Am. J. Anat. 166: 393-416.

41. Tiollier, J., Dumas, H., Tardy, M., and Tayot, J. L.1990. Fibroblast behavior on gels of type I, III, and IV human placental collagens. Exp. Cell Res. 191: 95-104.

42. Weidenreich, F. 1901. Das gefasssystem der menschlichen Milz. Arch. f. Mikr. Anat. 58: 247-376. 